\title{
geosciences
}

ISSN 2076-3263

www.mdpi.com/journal/geosciences

Article

\section{Impacts of Artisanal and Small-Scale Gold Mining (ASGM) on Environment and Human Health of Gorontalo Utara Regency, Gorontalo Province, Indonesia}

\author{
Yayu Indriati Arifin ${ }^{1,2, *}$, Masayuki Sakakibara ${ }^{1, \dagger}$ and Koichiro Sera ${ }^{3, \dagger}$
}

1 Graduate School of Science \& Engineering, Ehime University, 2-5 Bunkyo-cho, Matsuyama 790-8577, Japan; E-Mail: sakakiba@sci.ehime-u.ac.jp

2 Department of Geology, State University of Gorontalo, Jl. Jend. Sudirman No. 6 Kota Gorontalo, Gorontalo 96128, Indonesia

3 Cyclotron Research Center, Iwate Medical University, 348-58 Tomegamori, Takizawa, Iwate 020-0173, Japan; E-Mail: ksera@iwate-med.ac.jp

$\dagger$ These authors contributed equally to this work.

* Author to whom correspondence should be addressed; E-Mail: yayu_arifin@ung.ac.id; Tel.: +81-089-927-9649; Fax: +81-089-927-9640.

Academic Editors: Jose A. Centeno, Robert B. Finkelman and Olle Selinus

Received: 29 December 2014 / Accepted: 8 April 2015 /Published: 16 April 2015

\begin{abstract}
Mercury concentrations in the environment (river sediments and fish) and in the hair of artisanal gold miners and inhabitants of the Gorontalo Utara Regency were determined in order to understand the status of contamination, sources and their impacts on human health. Mercury concentrations in the sediments along the Wubudu and Anggrek rivers are already above the tolerable level declared safe by the World Health Organization (WHO). Meanwhile, commonly consumed fish, such as snapper, have mercury levels above the threshold limit $(0.5 \mu \mathrm{g} / \mathrm{g})$. The mean mercury concentrations in the hair of a group of inhabitants from Anggrek and Sumalata are higher than those in hair from control group (the inhabitants of Monano, Tolinggula and Kwandang). The mean mercury concentration in the hair of female inhabitants is higher than that in the hair of male inhabitants in each group. Neurological examinations were performed on 44 participants of artisanal and small-scale gold mining (ASGM) miners and inhabitants of Anggrek and Sumalata. From the 12 investigated symptoms, four common symptoms were already observed among the participants, namely, bluish gums, Babinski reflex, labial reflex and tremor.
\end{abstract}


Keywords: mercury; ASGM; Gorontalo Utara Regency

\section{Introduction}

Indonesia is perhaps the world's second largest mercury emitter from artisanal and small-scale gold mining (ASGM) [1]. It is estimated that about 125 and 145 tons of mercury was emitted in 2000 and 2005 , respectively [1,2]. Rapid growth of mercury emission may be related to intensive mining activities in existing ASGM sites and the opening of new ASGM sites. Sulawesi Island is home of ASGM sites with huge mercury emissions per year, with Poboya in Palu of central Sulawesi Province and Talawaan in Minahasa of North Sulawesi Province [3].

The Gorontalo Province of Northern Sulawesi, Indonesia, has several artisanal and small-scale gold mining (ASGM) sites in each Regency: (1) Pohuwato Regency: Gunung Pani and Bulontio; (2) Boalemo Regency: Bilato; (3) Bone Bolango Regency: Tulabolo; and (4) Gorontalo Utara Regency: Hulawa and Ilangata villages. The ASGM activities in the Hulawa village of the Sumalata subdistrict began in the 1970s, while the ASGM activities in Ilangata and the Ilangata Barat villages of the Anggrek subdistrict just started five years ago. Every year, approximately $572 \mathrm{~kg}$ of mercury contaminates the environment of the Gorontalo Utara Regency [4]. Yet, there is no report on the status of the environmental pollution related to the ASGM activities in the Gorontalo Utara Regency.

The mercury pollution in the environment (river sediment and fish) related to the ASGM activities in North Sulawesi is reported as baseline information in the subjects [5,6]. For a fish-eating community, such as the Gorontalo Utara inhabitants, data on mercury levels in fish are needed for determining the sources of mercury exposure in the human body [7-9]. Mercury contaminations and health assessments of miners and inhabitants from some ASGM sites in Indonesia, namely, Talawaan, Tatelu, Galangan and Sekotong, have been reported [3,10-13]. Mercury concentration in human hair is often used as a bioindicator of the mercury levels in the human body. Human hair is sampled for the determination of mercury levels in the human body. It has many advantages because it is easy to collect, handle, and analyze and can record the contamination history over a long period [14-16]. In addition to mercury, more than 40 elements have so far been detected in hair [17-19].

The health status of miners is mainly determined by following a standardized protocol performed by medical doctors. The relationships among the mercury in hair, habits, health status and localization of ASGM are often discussed [20,21]. Scalp hair analysis was used as the first step for a risk assessment of heavy metal exposure to the human body for people who are working and living in the vicinity of a mine area, outside of such an area and in a metropolitan city [12,22-26]. The advantages of using hair samples for monitoring the impact of environmental pollution on human health are reported elsewhere [27,28].

This study is aimed at determining the status of mercury contamination in people of the Gorontalo Utara Regency, those living near ASGM sites and others who are living in Gorontalo Utara. The possible sources of contamination will also be investigated. The health conditions of the miners and inhabitants living around the mining sites were investigated using a standard neurological examination protocol. 


\section{Experimental Section}

\subsection{Study Area}

Samples were collected from five districts in the Gorontalo Utara Regency: Anggrek, Kwandang, Monano, Sumalata and Tolinggula (Figure 1). Geographically, Tolinggula, Sumalata, Monano, Anggrek and Kwandang are situated on hills and mountains along the coastline of the Gorontalo Utara Regency. Inhabitants of the Gorontalo Utara Regency mainly work as farmers and fishermen. Marine fish are commonly part of their diets, along with rice, corn and vegetables, which are also produced on the nearby hills alongside the coastline.
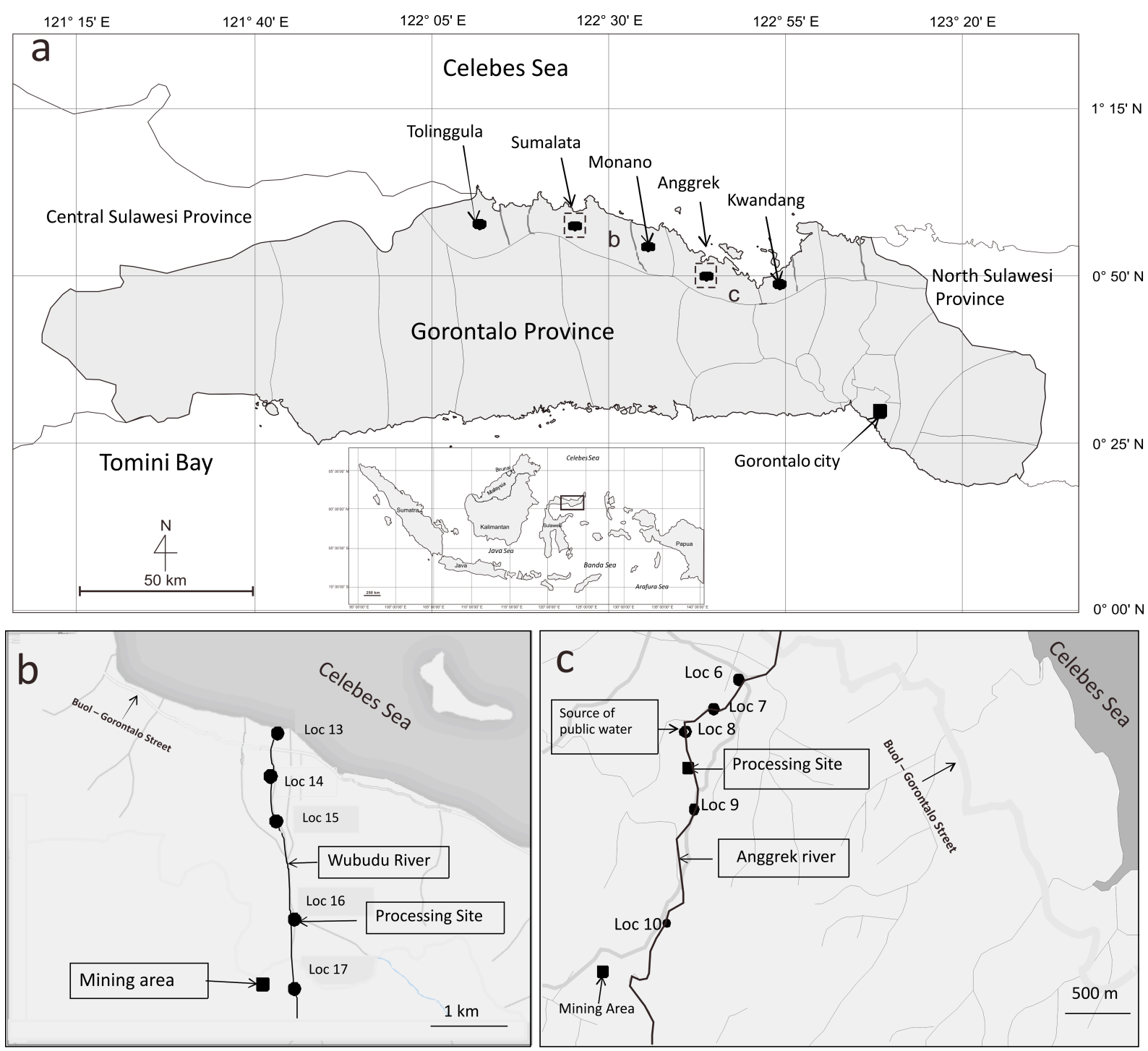

Figure 1. (a) Gorontalo Province map showing sampling locations (•) of human hair from Gorontalo Utara Regency, showing Tolinggula Sumalata, Anggrek, Monano and Kwandang districts. Location of Gorontalo Province in Indonesian map is shown (inset). The two rectangular shapes are ASGM locations and sampling sites for sediments and fishes; (b) Map of Sumalata gold mining site, showing locations $(\bullet)$ are sediment sampling sites and (c) map of Anggrek gold mining site, showing locations $(\bullet)$ are sediment sampling sites. Information on locations of ASGM ore extraction and processing sites are given in the text. 
The ASGM activities in the Sumalata and Anggrek districts are located along the Wubudu and Anggrek riverbanks, respectively (Figure 1). Information on the locations, where a sediment sample was collected (locations 6, 7, 8, 9 and 10), is provided below. Some ASGM processing sites are close to locations 6, 7 and 8. There are no ASGM activities close to location 9, but between locations 9 and 10, there is a significant amount of ASGM activities on the river. Meanwhile, an ASGM ore extraction and processing site is close to location 10.

ASGM processing (panning and amalgamation) occurs on the estuary of the Wubudu River, close to location 13. On the Wubudu riverbank between locations 14 and 15, we found many ASGM ore processing sites. Many ASGM processing sites are found around location 16, while there is an ASGM ore extraction and processing site close to location 17. The activities may contaminate the environment, as well as the Wubudu and Anggrek rivers and their estuaries.

The bioaccumulation of mercury, which may occur in living organisms such as paddy rice, corn and marine fish, become agents that spread mercury contamination through the food web of inhabitants of the Gorontalo Utara Regency. The mercury concentration in river sediments and fish will be used as background information about the mercury in the biotic and abiotic environments.

The Sumalata and Anggrek districts are locations with ASGM activities, while Kwandang, Monano and Tolinggula are districts without mining activities. The residents of Anggrek and Sumalata are considered the ASGM miners group, while the residents of Kwandang, Monano and Tolinggula are considered the control group.

\subsection{Sampling}

\subsubsection{Hair}

Human scalp hair samples were taken from 95 participants from inhabitants of Anggrek $(n=25)$, Sumalata $(n=23)$ and other regions of the Gorontalo Utara Regency (Kwandang $(n=7)$, Monano $(n=37)$ and Tolinggula $(n=4))$ between 2012 and 2013. Of the 95 participants, 53 were female, and the mean age was 23 years (range: 8 months-63 years). Among the 95 participants, 19 were ASGM workers, 15 were housewives, six were unemployed, one was teacher, one was university student and 38 were children (participants with ages below 18 years old).

The mercury concentrations in the hair samples from Anggrek, Kwandang, Monano, Sumalata and Tolinggula were determined to understand the status of contamination. The distribution of participants according to sex, location and occupation are summarized in Table 1. Approximately 10-20 strands of hair was cut close to skin from the right back side (mastoidal region of the temporal bone) and then labeled and stored in a sample plastic bag [28].

The mercury concentration in hair samples will be used to characterize the risk through a comparison with reference values published by the German Human Biomonitoring Commission in 1999 (Commission Human-Biomonitoring of the Federal Environmental Agency Berlin, 1999) [29]. The German Human Bio Monitoring (HBM) commission established toxicology threshold limits, which can be put into three categories. The first category is normal or HBM I, where the mercury level in hair is below $1 \mu \mathrm{g} / \mathrm{g}$. The above normal category is an alert level between HBM I and HBM II, where the mercury hair content is from 1 to $5 \mu \mathrm{g} / \mathrm{g}$. Meanwhile, above $5 \mu \mathrm{g} / \mathrm{g}$ is categorized in the high level or over HBM II. 


\subsubsection{Sediment}

We collected several sediment samples along the Sumalata and Anggrek Rivers, and the locations of the sampling points are shown in Figure 1. Approximately up to $15 \mathrm{~cm}$ from the river bed sediment was collected using a shovel and stored in a plastic bag, which was kept in a cool box. The sample was collected from several points at one location, according to the averaging principle [30].

\subsubsection{Fish}

Several marine fish species anchovy (Engraulis japonicus), gray snapper (Lutjanus griseus), yellow tail snapper (Ocyurus chrysurus), redbelly yellowtail fusilier (Caesio cuning), red snapper (Lutjanus sp.), and lane snapper (Lutjanus synagris) were bought from local fishermen of the Sumalata river estuary area. The samples were placed in plastic bags and stored in a cool box. The mercury concentrations in fish were determined using cold vapor AAS (CVAAS of Varian AA240 FS).

\subsection{Analytical Procedure}

\subsubsection{Particle Induced X-Ray Emission (PIXE)}

Elemental analysis for the scalp hair samples was performed by particle induced x-ray emission (PIXE) in the Cyclotron Research Center, Iwate Medical University, Japan. The precision and accuracy of this method have been reported elsewhere [31-35]. Hair samples were washed using Milli-Q water and shaken in an ultrasonic bath for $1 \mathrm{~min}$. Then, the samples were dried by wiping them with a tissue. The dried hair samples were washed again by being stirred in acetone for $5 \mathrm{~min}$. Then, they were washed again using Milli-Q water, wiped well with tissue and left to dry at room temperature. The hair samples (approximately seven hairs per person) were stuck on a target holder. A 2.9 MeV-proton beam hit the target after passing through a beam collimator of graphite, whose diameter was $6 \mathrm{~mm}$. X-rays of energy higher than that of the $\mathrm{K}-\mathrm{K}_{\alpha}$ line were detected by a $\mathrm{Si}(\mathrm{Li})$ detector $(25.4 \mu \mathrm{m}$ thick Be window; $6 \mu \mathrm{m}$ active diameter) with a $300 \mu \mathrm{m}$-thick Mylar absorber. For measurements of X-rays lower than the K-K $\mathrm{K}_{\alpha}$ line, a $\mathrm{Si}(\mathrm{Li})$ detector ( $80 \mathrm{~mm} \mathrm{Be} ; 4 \mathrm{~mm}$ active diameter), which has a large detection efficiency for low energy X-rays, was used. Descriptions of the data acquisition system and the measuring conditions are reported elsewhere [33]. The typical beam current and integrated beam charge were $100 \mathrm{nA}$ and $40 \mathrm{mC}$, respectively. The procedure for the standard-free method for untreated hairs is almost the same as that reported in the previous studies [31].

\subsubsection{Atomic Absorption Spectroscopy}

The mercury concentrations in the sediments and fish species were determined using cold vapors AAS (CVAAS of Varian AA240 FS) in BPPM Gorontalo, since those samples need quick and special treatment compared to human hair samples. Accuracy and Standard procedure used in AAS are certified by Indonesian Government and they used standard procedures.

The threshold limit for mercury in river sediments is $10 \mu \mathrm{g} / \mathrm{kg}$ [36]. The threshold limit for mercury in fish and its product is $0.5 \mu \mathrm{g} / \mathrm{g}$, according to the Bureau of Food and Drug Supervision of the Ministry of 
Health of the Republic of Indonesia, which is consistent with the recommended safety levels of WHO/ICPS [36].

Fish samples were washed with distilled water and dried in tissue paper after defrosting in the laboratory. A portion of the edible muscle tissue was removed from the dorsal part of each fish, homogenized and stored in clean-capped glass vials in a freezer until analysis. The fish samples were digested for total mercury determination by an open flask procedure developed at National Institute for Minamata Disease (NIMD) in Japan by Akagi and Nishimura [37,38].

Sediment samples were dried in oven for $24 \mathrm{~h}$ at $40{ }^{\circ} \mathrm{C}$, cleaned from parts dead animal and plants. Sediment samples were powdered using Agate mortar for about two hours. Powdered sediment samples were sent to BPPMHP for AAS measurement.

\subsection{Neurological Examination}

Neurological examinations were performed on a limited number of participants by a team of medical doctors using a standard protocol. The participants were 27 people from Sumalata and 17 people from Anggrek. The examinations were conducted on site: mining sites for the miners and at home for the inhabitants. A total of 12 symptoms related to mercury poisoning were included in the neurological examination: (1) Signs of bluish discoloration of gums; (2) Rigidity and ataxia (walking or standing); (3) Alternating movements or dysdiadochokinesia; (4) Irregular eye movements or nystagmus; (5) Field of vision; (6) Knee jerk reflex; (7) Biceps reflex; (8) Babinski reflex; (9) Labial reflex; (10) Salivation and dysarthria; (11) Sensory examination; and (12) Tremor: tongue, eyelids, finger to nose, pouring, posture holding and the Romberg test. We used 1 and 0 for positively and negatively observed symptoms, respectively.

\subsection{Statistical Analysis}

The mercury hair sample and neurological examination data were analyzed statistically with Origin (OriginLab (2007) version 8.0). Kolmogorov-Smirnov tests were used to study the normality of the distribution of inhabitant mercury hair samples. Because the data are log-normally distributed, the Kruskal-Wallis ANOVA test was used to identify differences among the subgroups. The relationship between the mercury concentration and age of participant in both groups is determined using the Spearman correlation coefficient.

\section{Results and Discussion}

\subsection{Mercury in Hairs}

The distributions and range of mercury levels in 95 hair samples collected from the five subdistricts are summarized in Table 1 . The hair mercury concentrations of all participants are more than $1 \mathrm{mg} / \mathrm{g}$, which indicates the toxicity level is already in alert level according to HBM [29]. The number of subjects with high mercury levels over $10 \mu \mathrm{g} / \mathrm{g}$ was 10 (40\%), 7 (30.4\%), and 4 (8.5\%) in Anggrek, Sumalata, and the control group (Kwandang, Monano and Tolinggula), respectively. According to the Kolmogorov-Smirnov test, the distribution of data of mercury hair from the Gorontalo Utara Regency 
was not normal; instead, it had a log normal distribution. The geometrical mean is more suitable for log normal distribution data.

Table 1. Geometrical mean, standard deviation and range of hair mercury content of inhabitants of Gorontalo Utara Regency.

\begin{tabular}{|c|c|c|c|c|c|}
\hline \multirow{2}{*}{ Residence } & \multirow{2}{*}{ Sex } & \multirow{2}{*}{$N$} & \multicolumn{3}{|c|}{ Hair Mercury Content $(\mu \mathrm{g} / \mathrm{g})$} \\
\hline & & & Mean \pm SD & Min & Max \\
\hline \multirow[t]{3}{*}{ Anggrek } & $\mathrm{F}$ & 11 & $14.2 \pm 2.9$ & 4.7 & 144.8 \\
\hline & $\mathrm{M}$ & 14 & $7.0 \pm 1.9$ & 2.1 & 17.9 \\
\hline & Total & 25 & $9.6 \pm 2.5$ & 2.1 & 144.8 \\
\hline \multirow[t]{3}{*}{ Kwandang } & $\mathrm{F}$ & 6 & $6.7 \pm 1.6$ & 4.0 & 14.6 \\
\hline & M & 1 & $3.5 \pm$ & 3.5 & 3.5 \\
\hline & Total & 7 & $6.1 \pm 1.7$ & 3.5 & 14.6 \\
\hline \multirow[t]{3}{*}{ Monano } & $\mathrm{F}$ & 22 & $6.2 \pm 1.6$ & 2.8 & 28.1 \\
\hline & M & 15 & $5.0 \pm 1.3$ & 3.5 & 6.9 \\
\hline & Total & 37 & $5.7 \pm 1.5$ & 3.8 & 28.1 \\
\hline \multirow[t]{3}{*}{ Sumalata } & $\mathrm{F}$ & 11 & $10.0 \pm 2.1$ & 3.8 & 69.8 \\
\hline & M & 12 & $6.6 \pm 1.7$ & 2.5 & 13.7 \\
\hline & Total & 23 & $8.0 \pm 2.0$ & 2.5 & 69.8 \\
\hline \multirow[t]{3}{*}{ Tolinggula } & $\mathrm{F}$ & 3 & $5.0 \pm 1.2$ & 4.4 & 5.9 \\
\hline & M & 0 & & & \\
\hline & Total & 3 & $5.0 \pm 1.2$ & 4.4 & 5.9 \\
\hline \multirow[t]{3}{*}{ Total } & $\mathrm{F}$ & 53 & $8.1 \pm 2.1$ & 2.8 & 144.8 \\
\hline & M & 42 & $6.0 \pm 1.7$ & 2.1 & 17.9 \\
\hline & Total & 95 & $7.1 \pm 2.0$ & 2.1 & 144.8 \\
\hline
\end{tabular}

\subsubsection{Mercury Concentration for Males and Females}

The lognormal distribution of hair mercury levels in males and females is shown in Figure 2. Five females had mercury levels greater than $25 \mu \mathrm{g} / \mathrm{g}$, and none of them worked as ASGM miners. Those five females may have been exposed to mercury from another source (affecting female inhabitants only). The elevated hair mercury levels that were above average $(7.1 \mu \mathrm{g} / \mathrm{g})$ and even the highest $(17.9 \mu \mathrm{g} / \mathrm{g})$ mercury level were found among the ASGM miners.

The average hair mercury levels for all, male and female inhabitants in the Monano district are 5.7, 5.0 and $6.2 \mu \mathrm{g} / \mathrm{g}$, respectively. These levels show that there are no significant differences between the mean hair mercury of males and females in that district. While the average of all mercury hair content for females is $8.1 \mu \mathrm{g} / \mathrm{g}$ (more than 30 percent higher than males $(6.0 \mu \mathrm{g} / \mathrm{g})$ ), such conditions were also found for the subgroups of Kwandang and Sumalata. The condition in Anggrek is even higher (three times). The large discrepancy of mercury levels between female and male inhabitants suggests that female inhabitants are receiving mercury from another source (e.g., whitening cream).

\subsubsection{Relation between Mercury Concentration and Age}

The mercury concentration in human hairs depends on several factors, including age. Figure 3 shows the mercury concentrations $v s$. the age of miners and non-miners. There is a positive, strong and 
significant relationship $(r=0.31 ; p=0.01)$ between the age and mercury content of the group of inhabitants, while there was no significant correlation $(r=-0.16 ; p=0.44)$ for the group of miners. Such conditions imply that the hair mercury concentrations of non-miners are age dependent, while for miners, the correlation remains unknown. Some factors related to the hair mercury concentration were not considered here, including habits, food consumption and drugs.

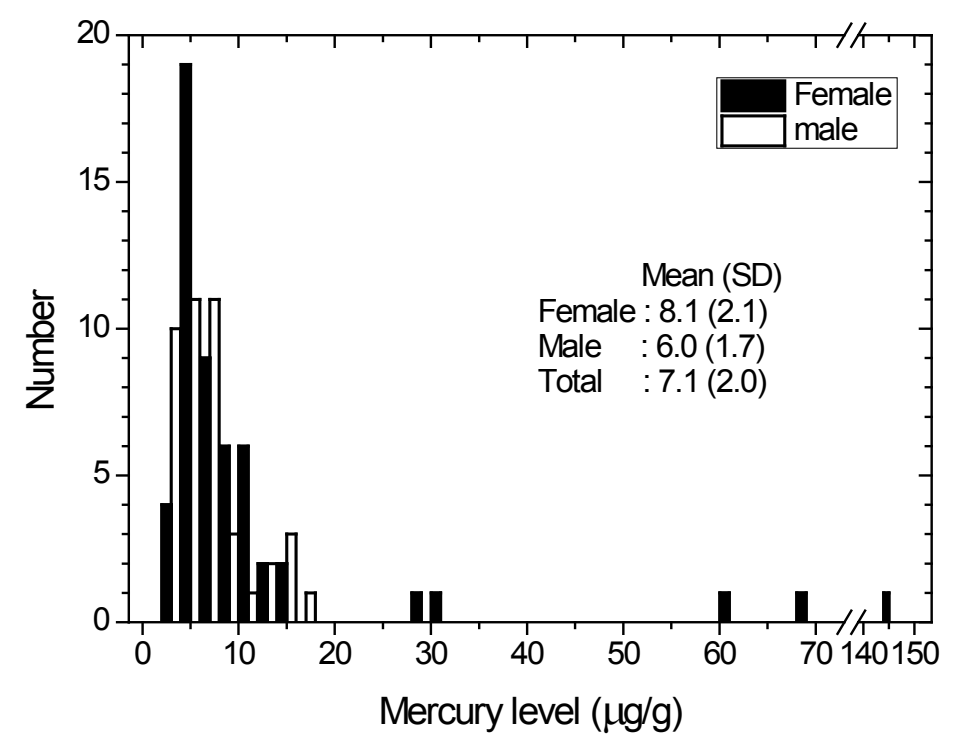

Figure 2. Distribution of the hair mercury among the total population. Open bar and solid bar indicate male and female, respectively. Geometrical mean and Standard Deviation are shown for male, female and total.

The positive correlation of hair mercury levels and age of the non-ASGM miner population is related to the inhabitants; constant consumption of mercury in their diets, which are already contaminated by mercury. Meanwhile, the lack of a significant correlation for the ASGM miners is not as important, given that the majority of ASGM miners have mercury levels above the non-miners.

Children (below 18 years old) had higher mercury hair levels for several reasons: spending more time playing outdoors, hand-to-mouth behavior, lower ability to metabolize certain contaminants, etc.

\subsubsection{Relation between Mercury Concentration and Localization}

A comparison of the hair mercury distribution among inhabitants of the Anggrek and Sumalata districts (ASGM site) and inhabitants of other districts without an ASGM site is shown in Figure 4. The mean hair mercury concentrations (SD) of the ASGM site and non-ASGM site groups are $8.8(2.2) \mu \mathrm{g} / \mathrm{g}$ and $5.7(1.5) \mu \mathrm{g} / \mathrm{g}$, respectively. We used the Kruskal-Wallis test to identify the differences between groups, and there was no significant difference in the $95 \%$ level of confidence.

An effect of localization could be observed, as both groups were receiving the same source of mercury in their diet (food and fish from the same source). However, the mean hair mercury level of inhabitants of the ASGM site is higher than that in the non-ASGM site, indicating there is another source of mercury that corresponds to the ASGM activities. The most probable source of the elevated mercury level in inhabitants of the ASGM site is the mercury vapor from smelting processes, which mainly occurs outside, in gold shops and sometimes inside houses. The mercury emissions from gold shops 
could reach up to $53.4 \mu \mathrm{g} / \mathrm{m}^{3}$, whereas the normal atmospheric level in rural areas is approximately $0.002-0.004 \mu \mathrm{g} / \mathrm{m}^{3}[39]$.

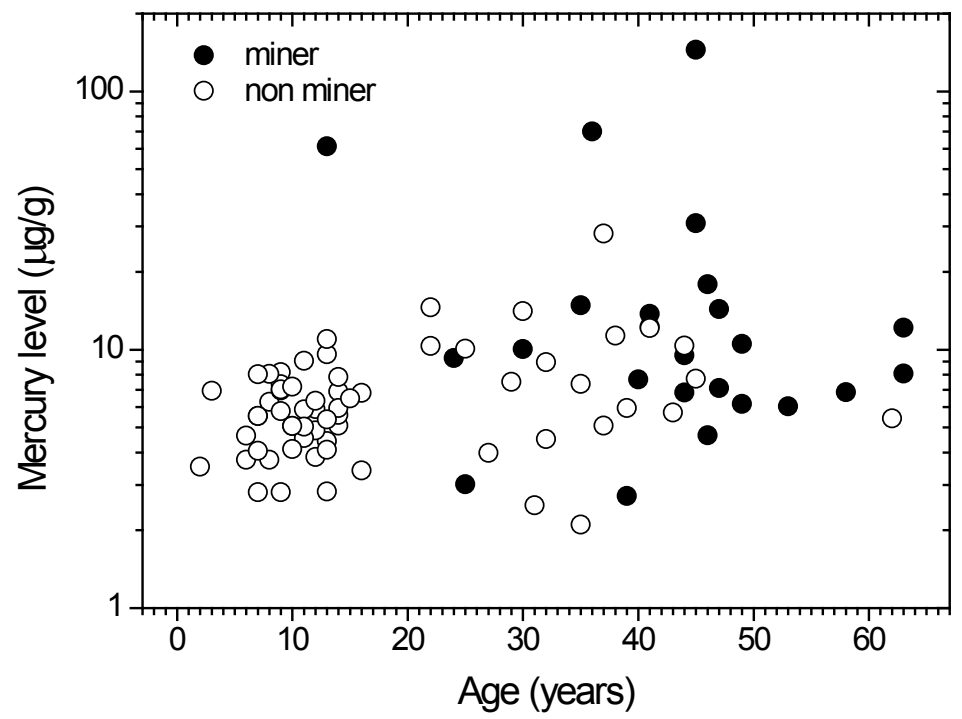

Figure 3. Distribution of mercury level among population of Gorontalo utara Regency. Open $(\circ)$ and closed $(\bullet)$ symbols denoted for non miner and miner groups, respectively.

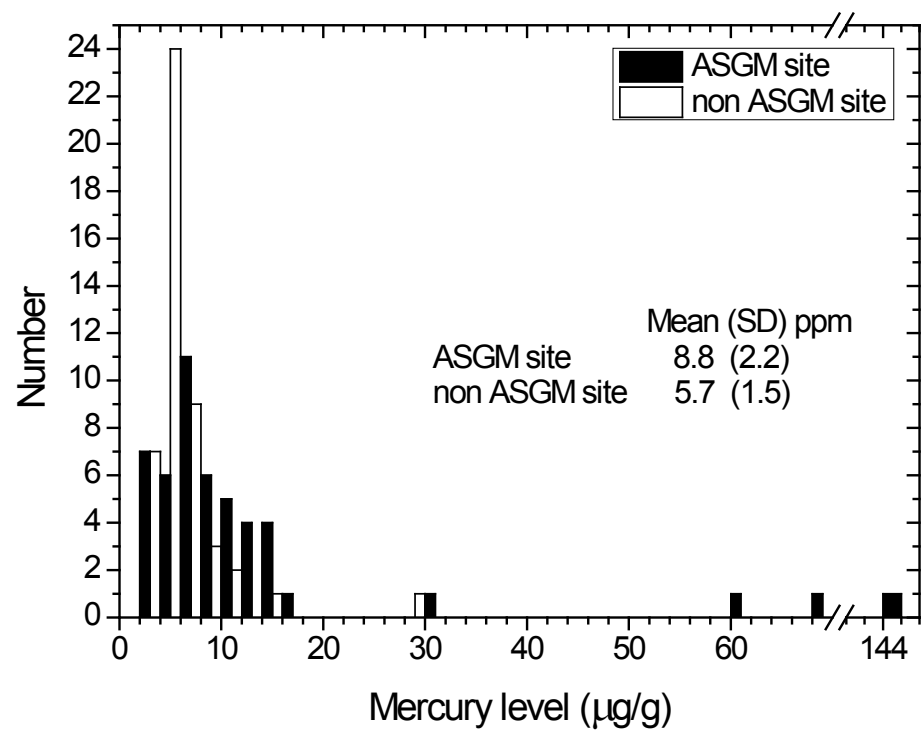

Figure 4. Distribution of the hair mercury among the total population according to their location from ASGM. Black and white bar indicate ASGM site inhabitants and non ASGM site inhabitants, respectively. Mean and standard deviation (SD) for both groups are given on the graph.

\subsubsection{Results Comparison with Other Publications}

Hair mercury concentrations of inhabitants from control areas (Kwandang, Monano and Tolinggula districts) will be treated as background levels. In the Table 2 mercury in human hairs from control areas of this study is compared with other publications. Elevated background level of hair mercury concentrations in Gorontalo Utara Regency is similar to high fish consumption areas, such as Philippines 
and Sulawesi; and far above lower fish consumption areas such as Tanzania and Mongolia. The fish consumption is most likely become the only factor determining the background levels of hair mercury concentration [40]. The values of background mercury levels of high fish consumption areas is may depends on mercury content on most eatable fish species and frequency of eating fish.

Table 2. Hair mercury concentrations $(\mu \mathrm{g} / \mathrm{g})$ of inhabitants from control areas of this study compared to other publications [40].

\begin{tabular}{cccccc}
\hline & This Study & Indonesia-Sulawesi & Philippines & Tanzania & Mongolia \\
\hline Number & 47 & 20 & 39 & 24 & 34 \\
Minimum & 2.8 & 0.83 & 0.98 & 0.08 & 0.03 \\
Mean & 5.7 & 1.64 & 4.02 & 0.36 & 0.1 \\
Maximum & 28.1 & 3.72 & 34.71 & 0.68 & 0.62 \\
\hline
\end{tabular}

\subsection{Mercury in River Sediments and Fishes}

The mercury concentrations in the Wubudu River sediments are shown in Figure 5. All values are already far above the threshold limits by WHO/ICPS [36]. Locations 15, 16 and 17 have higher mercury concentrations because they are close to the ASGM processing units, and the levels gradually decrease downstream (locations 13 and 14). The mercury concentration in location 16 is lower than that in 15 and 17 because it is located in the junction and then may be diluted by another river branch inlet (Figure 5).

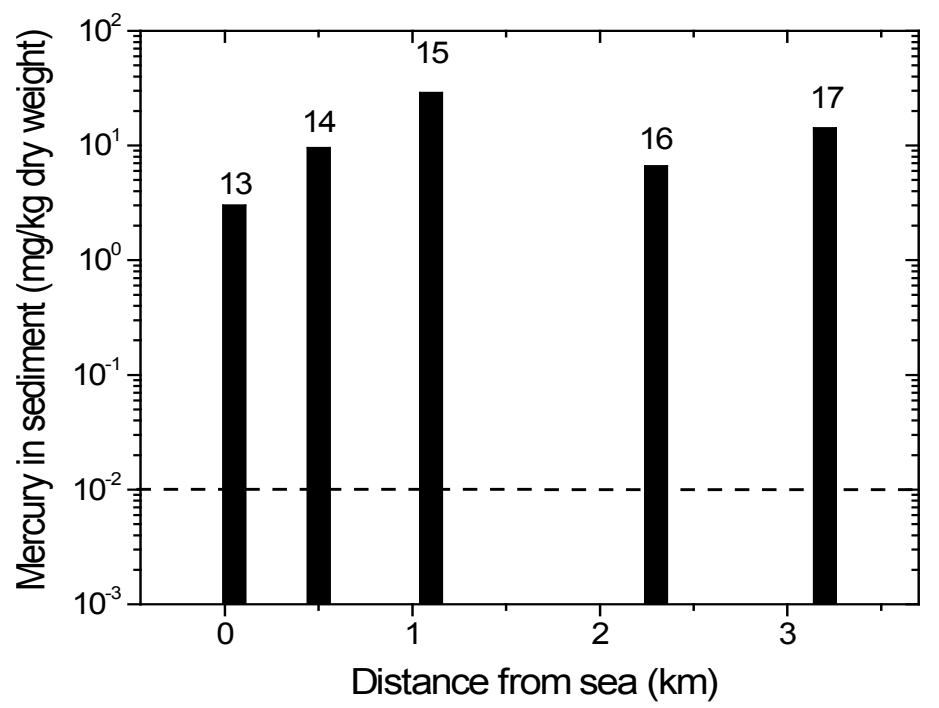

Figure 5. Mercury content in sediment from Wubudu river. Numbers on top of bars corresponds with sampling location. The dotted line indicates the recommended safety level (WHO/ICPS 1990).

The distribution of mercury concentrations in the river sediments is depicted in Figure 6. Locations 8, 9 and 10 are close to the ASGM processing site, while locations 6 and 7 are not (Figure 1). It is evident that the ASGM activities are the source of the elevated mercury levels in the sediments at locations 8, 9 and 10 (Figure 1). Although Figure 6 shows a connection between the branches in the Anggrek river system, our observations showed some river branches are disconnected due to the dry season. Compared to the Wubudu River, the Anggrek River is smaller, and several branches may be cut off during the dry season. 
The mercury concentrations in the fish are depicted in Figure 7. The values vary from species to species. Most species have mercury levels below the threshold, but the fish that are commonly consumed, such as snapper (Lutjanus synagris and Ocyurus chrysurus), already have mercury levels above the threshold limit by WHO/ICPS 1990 [36]. Although some common edible fish have mercury levels below the maximum tolerable limit by WHO/ICPS, the frequency of eating such fish is critical. WHO established provisional tolerable weekly intake (PTWI) about $2.5 \mathrm{~g} / \mathrm{kg}$ body weight in order to protect the fetus from neurotoxic effects [41].

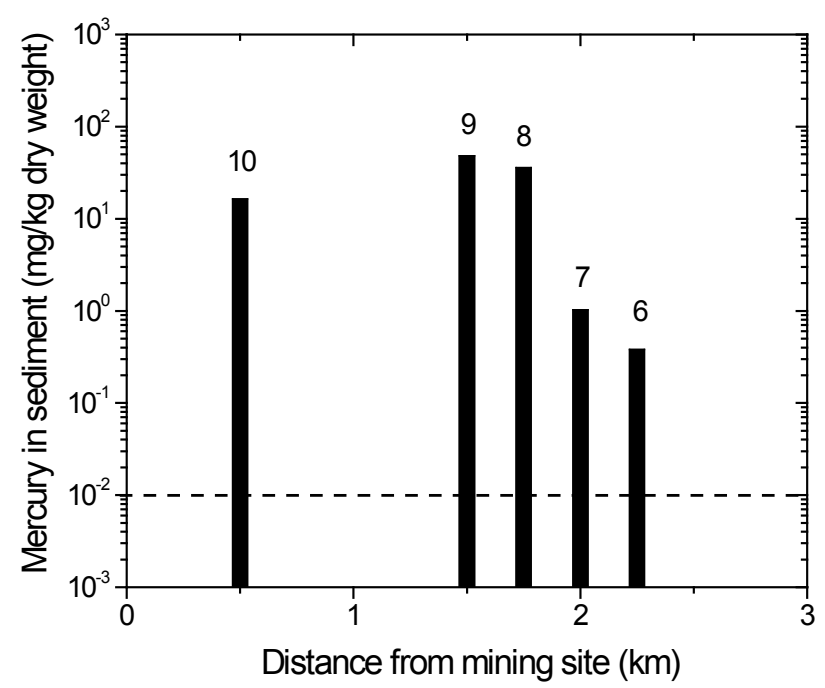

Figure 6. Mercury content in sediment of Anggrek Rivers. Numbers on top of bars correspond with sampling location. The dotted line indicates the recommended safety level (WHO/ICPS 1990).

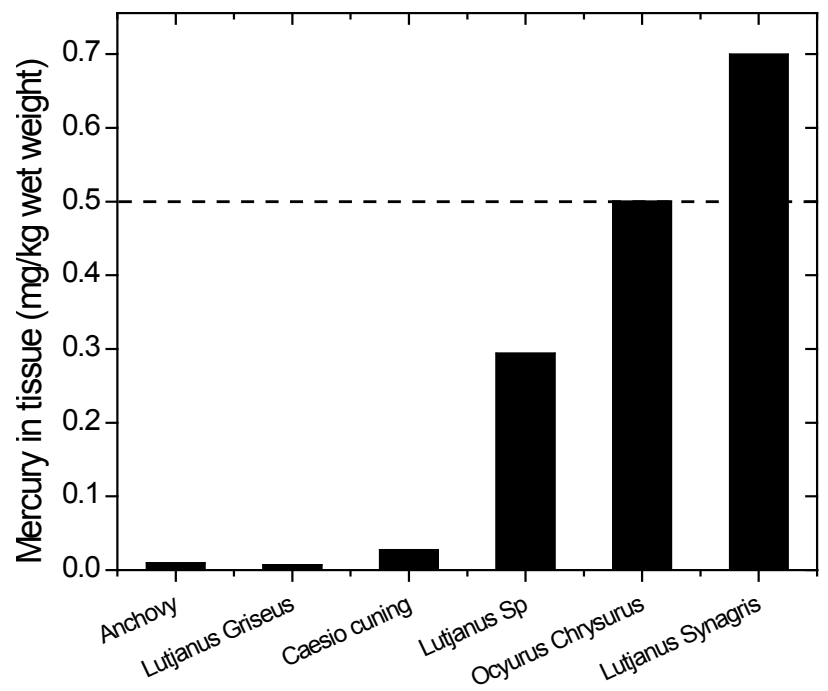

Figure 7. Mercury content in species of fish from Wubudu Estuary. The dashed line indicates the recommended safety level (WHO/ICPS 1990).

\subsection{Neurological Examinations}

From the 12 objective symptoms that were evaluated (Table 3), some common symptoms (bluish gums (1), Babinski reflex (8), labia reflex (9), and tremor (12)) were observed among the ASGM miners 
and inhabitants of Anggrek and Sumalata. The miners from Anggrek showed additional symptoms, namely rigidity and ataxia (2), alternating movements (3) and irregular eye movements (4).

No recent study has reported on mercury contamination using scalp hair as a bioindicator and the health effects of inhabitants of Gorontalo Utara Regency related to the ASGM activities in the Anggrek and Sumalata districts. Using scalp hair as a bioindicator of mercury contamination mainly reflects the uptake of the organic mercury compound via fish consumption [42,43].

The mean mercury levels of inhabitants from Anggrek and Sumalata are 14.2 and $10.0 \mu \mathrm{g} / \mathrm{g}$, respectively. The values are two times higher than the smallest mean value $(5.0 \mu \mathrm{g} / \mathrm{g})$ of the Tolinggula district. Of the 21 subjects that have mercury hair concentrations greater than $10 \mu \mathrm{g} / \mathrm{g}, 15$ (71.4\%) of them are females, and four (26.7\%) of those females live outside the ASGM area. Females that have hair mercury concentrations greater than $10 \mu \mathrm{g} / \mathrm{g}$ have the potential to contaminate their fetuses, risking abnormal brain development [44].

The dominant positive symptoms observed in the miners and inhabitants are described in Figure 8. The common neurological disturbances that were observed among the ASGM miners and inhabitants of Anggrek and Sumalata are bluish gums, Babinski reflex, labial reflex and tremor. However, the Anggrek miners showed more positive symptoms, namely rigidity and ataxia (walking or standing), alternating movements or dysdiadochokinesia, irregular eye movements or so called nystagmus. Harari et al., found that tremor was a dominant symptoms among Ecuadorian gold miners, while Tomicic et al., observed that ataxia and tremor are dominant symptoms among Burkina Fassian gold miners $[45,46]$.

Table 3. Objective symptoms observed of the participants.

\begin{tabular}{ccccccccccccc}
\hline \multirow{2}{*}{ Groups (Number of Person) } & \multicolumn{11}{c}{ Symptoms } \\
\cline { 2 - 13 } & $\mathbf{1}$ & $\mathbf{2}$ & $\mathbf{3}$ & $\mathbf{4}$ & $\mathbf{5}$ & $\mathbf{6}$ & $\mathbf{7}$ & $\mathbf{8}$ & $\mathbf{9}$ & $\mathbf{1 0}$ & $\mathbf{1 1}$ & $\mathbf{1 2}$ \\
\hline Anggrek Miners (4) & 3 & 3 & 3 & 3 & 2 & 0 & 0 & 3 & 3 & 1 & 3 & 4 \\
Anggrek Inhabitants (13) & 3 & 2 & 2 & 2 & 1 & 2 & 2 & 10 & 10 & 3 & 5 & 4 \\
Sumalata Miners (4) & 4 & 1 & 1 & 1 & 1 & 1 & 1 & 3 & 3 & 0 & 0 & 3 \\
SumalataInhabitants (23) & 20 & 2 & 2 & 2 & 5 & 5 & 2 & 20 & 20 & 2 & 2 & 15 \\
\hline
\end{tabular}

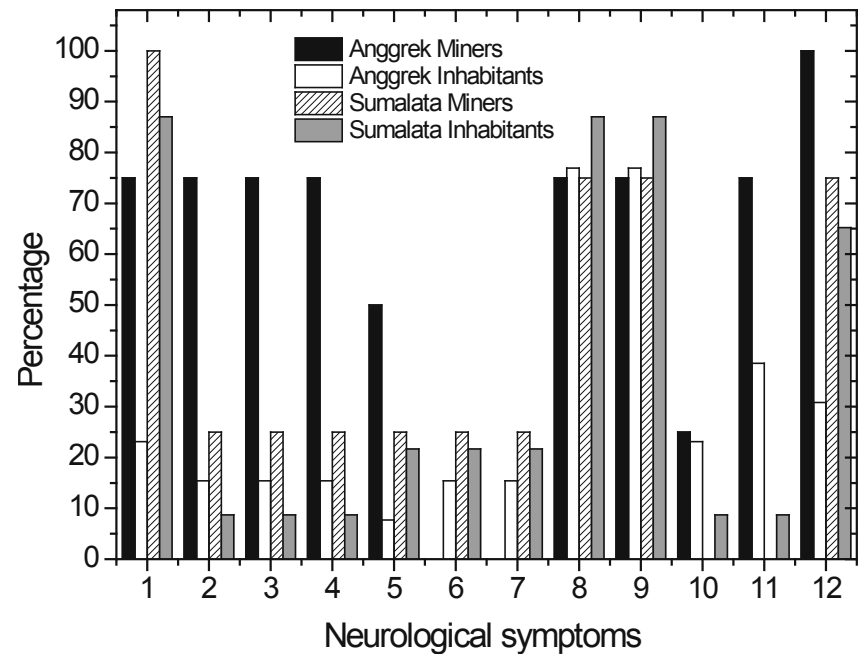

Figure8. Percentage of positive symptoms observed in ASGM miners and inhabitants of Sumalata and Anggrek. Babinski reflex(8)and labial reflex(9) are common symptoms observed in all subgroups. 
The relationship between the level of methyl mercury in scalp hair and neurological abnormalities found in adults has been discussed by researchers [47,48]. Although the total hair mercury level found in miners and inhabitants of Anggrek who participated in neurological examinations are between 3.4 and $14.9 \mu \mathrm{g} / \mathrm{g}$, only Babinski reflex and labial reflex disturbances are dominant. On the other hand, the miners and inhabitants of Sumalata with lower total hair mercury levels $(6.1-10.4 \mu \mathrm{g} / \mathrm{g})$ already showed at least four disturbances (Babinski reflex, labial reflex, bluish gums and tremor). We can assume that the methyl mercury levels of the Sumalata groups are higher than those of the Anggrek group because they were exposed for a longer period of time [49,50]. The high mercury concentrations in the Wubudu estuary sediments and fish (e.g., snapper) are the elevated mercury level sources for the Sumalata inhabitants.

\section{Conclusions}

The contamination status of groups of inhabitants who are living around the ASGM sites (Anggrek and Sumalata) and outside the sites (Monano, Kwandang and Tolinggula) is very high, according to HBM levels. The higher risk of mercury contamination due to the ASGM activities in ASGM sites is indicated by the higher mean hair mercury levels of inhabitants of the ASGM sites compared to those of inhabitants of the non-ASGM sites. Females have higher mean hair concentrations than males, and this result shows that female inhabitants are more vulnerable to mercury contamination. A significant and positive correlation found for the hair mercury levels and age of non-miner inhabitants suggests that living in ASGM sites potentially leads to mercury contamination.

The mercury concentrations of the Wubudu river sediments of Sumalata are above the threshold limits set by WHO, and the distribution is strongly related to the location of ASGM processing sites along the Wubudu riverbanks. The mercury concentrations of the Anggrek river sediments are already above the threshold limit set by WHO. The mercury levels in commonly consumed fish, which were caught in the Sumalata and Anggrek rivers and estuaries, are also reported. Most commonly consumed fish species (Lutjanus synagris and Ocyurus chrysurus) in the Regency have mercury levels above the maximum tolerable limits of the WHO [36]. Serious health problems are indicated by the dominant symptoms observed among the ASGM inhabitants, including bluish gums, Babinski reflex, labial reflex and tremor.

The proposed route for mercury to enter the human body is only an indirect way through the food web of the inhabitants, while ASGM miners receive a combination of indirect and direct exposure to mercury vapor including from smelting processes and direct contact with liquid mercury.

\section{Acknowledgments}

The authors wish to thank the government of Gorontalo Utara Regency, Indonesia for allowing us to conduct research and its support with sampling. One author (YIA) wishes to thank the Japanese Government for providing a Monbusho Scholarship for graduate studies in Ehime University.

\section{Author Contributions}

All authors contributed to the work presented in the manuscript. Yayu Indriati Arifin as principal researcher made substantial contribution to this work which was undertaken in association with her 
Ph.D. program. Masayuki Sakakibara as Ph.D. supervisor provided critical analyses and commentary during development of the manuscript. Koichiro Sera provided the PIXE measurement of hair samples, which is also a substantial contribution to the manuscript.

\section{Conflicts of Interest}

The authors declare no conflict of interest.

\section{References}

1. Veiga, M.M.; Maxson, P.A.; Hylander, L.D. Origin and consumption of mercury in small-scale gold mining. J. Clean. Prod. 2006, 14, 436-447.

2. Pacyna, E.P.; Pacyna, J.M.; Sundseth, K.; Munthe, J.; Kindborn, K.; Wilson, S.; Steenhuisen, F.; Mason, P. Global emission of mercury to the atmosphere from anthropogenic sources in 2005 and projections to 2020. Atmos. Environ. 2010, 44, 2487-2499.

3. Bose-O'Reilly, S.; Drasch, G.; Beinhoff, C.; Rodrigues-Filho, S.; Roider, G.; Lettmeier, B.; Maydl, A.; Maydl, S.; Siebert, U. Health assessment of artisanal gold miners in Indonesia. Sci. Total Environ. 2010, 208, 713-725.

4. Arifin, Y.A.; Sakakibara, M.; Takakura, S.; Jahja, M.; Lihawa, F.; Machmud, M. Artisanal and small-scale gold mining in Gorontalo Utara Regency, Indonesia. In Proceedings of the 23rd Symposium on Geo-Environments and Geo-Technics, Tsukuba, Japan, 29-30 November 2013; pp. 105-108.

5. Limbong, D.; Kumampung, J.; Ayhuan, D.; Arai, T.; Miyazaki, N. Mercury pollution related to artisanal gold mining in north Sulawesi Island, Indonesia. Bull. Envrion. Contam. Toxicol. 2005, 75, 989-996.

6. Agusa, T.; Kunito, T.; Iwata, H.; Monirith, I.; Tana, T.S.; Subramanian, A.; Tanabe, S. Mercury contamination in human hair and fish from Cambodia: Levels, specific accumulation and risk assessment. Environ. Pollut. 2005, 134, 79-86.

7. Vieira, H.C.; Morgado, A.; Soares, A.M.V.M.; Abreu, S.N. Mercury in scalp hair near the Mid-Atlantic Ridge (MAR) in relation to high fish consumption. Biol. Trace Elem. Res. 2013, 153, $29-35$.

8. Diringer, S.E.; Feingold, B.J.; Ortiz, E.J.; Gallis, J.A.; Araujo-Flores, J.M.; Berky, A.; Pan, W.K.Y.; Hsu-Kim, H. River transport of mercury from artisanal and small-scale gold mining and risks for dietary mercury exposure in Madre de Dios, Peru. Environ. Sci. Process Impacts. 2015, 17, $478-487$.

9. Niane, B.; Guédron, S.; Moritz, R.; Cosio, C.; Ngom, P.M.; Deverajan, N.; Pfeifer, H.R.; Poté, J. Human exposure to mercury in artisanal small-scale gold mining areas of Kedougou region, Senegal, as function of occupational activity and fish consumption. Environ. Sci. Pollut. Res. 2014, doi:10.1007/s11356-014-3913-5.

10. Castilhos, Z.C.; Rodrigues-Filho, S.; Rodrigues, A.P.C.; Villas-Boas, R.C.; Veiga, M.; Beinhoff, C. Mercury contamination in fish from gold mining areas in Indonesia and human health risk assessment. Sci. Total Environ. 2006, 368, 320-325. 
11. Bose-O’Reilly, S.; Lettmeier, B.; Gothe, R.M.; Beinhoff, C.; Siebert, U.; Drasch, G. Mercury as a serious health hazard for children in gold mining areas. Environ. Res. 2008, 107, 89-97.

12. Krisnayanti, B.D.; Anderson, C.W.N.; Utomo, W.H.; Feng, X.; Handayanto, E.; Mudarisna, N.; Ikram, H. Assessment of environmental mercury discharge at a four-year-old artisanal gold mining area on Lombok Island, Indonesia. J. Environ. Monit. 2012, 14, 2598-2607.

13. Wolowiec, P.; Michalak, I.; Chojnacka, K.; Mikulewicz, M. Hair analysis in health assessment: Invited critical review. Clin. Chim. Acta. 2013, 419, 139-171.

14. Kempson, I.M.; Lombi, E. Hair analysis as a biomonitor for toxicology, disease and health status: Critical review.Chem. Soc. Rev.2011, 40, 3915-3940.

15. Laffont, L.; Sonke, J.E.; Maurice, L.; Monrroy, S.L.; Chincheros, J.; Amouroux, D.; Behra, P. Hg speciation and stable isotope signatures in human hair as a tracer for dietary and occupational expossure to mercury. Environ. Sci. Technol. 2011, 45, 9910-9916.

16. Esteban, M.; Castaño, A. Non-invasive matrices in human biomonitoring: A review.Environ. Int. 2009, 35, 438-449.

17. Molina-Villalba, I.; Lacasaña, M.; Rodríguez-Barranco, M.; Hernández, A.F.; Gonzalez-Alzaga, B.; Aguilar-Garduño, C.; Gil, F. Biomonitoring of arsenic, cadmium, lead, manganese and mercury in urine and hair of children living near mining and industrial areas. Chemosphere 2015, 124, 83-91.

18. Król, S.; Zabiegała, B.; Namieśnik, J. Human hair as a biomarker of human exposure to persistent organic pollutants (POPs). TrAC Trends Analyt. Chem. 2013, 47, 84-98.

19. Li, Y.; Zhang, X.; Yang, L.; Li, H. Levels of $\mathrm{Cd}, \mathrm{Pb}, \mathrm{As}, \mathrm{Hg}$, and $\mathrm{Se}$ in hair of residents living in villages around Fenghuang Polymetallic Mine, southwestern China. Bull. Environ. Contam. Toxicol. 2012, 89, 125-128.

20. Chojnacka, K.; Górecka, H.; Górecki, H.The influence of living habits and family relationships on element concentrations in human hair. Sci. Total Environ. 2006, 366, 612-620.

21. Chojnacka, K.; Zielinska, A.; Michalak, I.; Gorecki, H. The effect of dietary habits on mineral composition of human scalp hair. Environ. Toxicol. Pharmacol. 2010, 30, 188-194.

22. Afridi, H.I.; Kazi, T.G.; Brabazon, D.; Naher, S. Assosication between essential trace and toxic elements in scalp hair samples of smokers rheumatoid arthritis subjects. Sci. Total Environ. 2011, 412-413, 93-100.

23. Olivero-Verbel, J.; Caballero-Gallardo, K.; Negrete-Marrugo, J. Relationship between localization of gold mining areas and hair mercury levels in people from Bolivar, North of Colombia. Biol. Trace Elem. Res. 2011, 144, 118-132.

24. Castilhos, Z.; Rodrigues-Filho, S.; Cesar, R.; Rodrigues, A.P.; Villas-Bôas, R.; de Jesus, I.; Lima, M. Human exposure and risk assessment associated with mercury contamination in artisanal gold mining areas in the Brazilian Amazon. Environ. Sci. Pollut. Res. 2015, doi:10.1007/s11356-015-4340-y.

25. Huang, M.; Wang, W.; Leung, H.; Chan, C.Y.; Liu, W.K.; Wong, M.H.; Cheung, K.C. Mercury levels in road dust and household TSP/PM 2.5 related to concentrations in hair in Guangzhou, China. Ecotoxicol. Eenviron. Safety 2012, 81, 27-35.

26. Peng, L.; Feng, X.; Zhang, C.; Zhang, J.; Cao, Y.; You, Q.; Leung, A.O.W.; Wong, M.H.; Wu, S.C. Human exposure to mercury in a compact fluorescent lamp manufacturing area: By food (rice and fish) consumption and occupational exposure. Environ. Pollut. 2015, 198, 126-132. 
27. Castaño, A.; Sánchez-Rodríguez, J.E.; Cañas, A.; Esteban, M.; Navarro, C.; Rodríguez-García, A.C.; Arribas, M.; Díaz, G.; Jiménez-Guerrero, J.A. Mercury, lead and cadmium levels in the urine of 170 Spanish adults: A pilot human biomonitoring study. Int. J. Hyg. Environ. Health 2012, 215, 191-195.

28. Varrica, D.; Tamburo, E.; Dongarrà, G.; Sposito, F. Trace elements in scalp hair of children chronically exposed to volcanic activity (Mt. Etna, Italy). Sci. Total Environ. 2014, 470, 117-126.

29. Schulz, C.; Angerer, J.; Ewers, U.; Kolossa-Gehring, M. The german human biomonitoring commission. Int. J. Hyg. Environ. Health. 2007, 210, 373-382.

30. Ohio Environmental Protection Agency. Sediment Sampling Guide and Methodologies. Available online: http://www.epa.ohio.gov/portals/35/guidance/sedman2001.pdf (accessed on 1 April 2015).

31. Kempson, I.; Skinner, W.M.; Kickbride, K.P. Advanced analysis of metal distribution in human hair. Environ. Sci. Technol. 2006, 40, 3423-3428.

32. Islam, S.M.D.; Sera, K.; Takatsuji, T.; Hossain, A.M.D.; Nakamura, T. Estimation of hair arsenic and statistical nature of arsenicosis in highly arsenic exposed Banglish village in Comilla district of Bangladesh. Int. J. PIXE 2011, 21, 101-118.

33. Sera, K.; Futatsugawa, S.; Matsuda, K. Quantitative analysis of untreated bio-samples. Nuclear Instrum.Method. Phys. Res. B. 1999, 150, 226-233.

34. Sera, K.; Futatsugawa, S.; Murao, S. Quantitative analysis of untreated hair samples for monitoring human exposure to heavy metals. Nuclear Instrum. Method. Phys. Res. B 2002, 189, 174-179.

35. Clemente, E.; Sera, K.; Futatsugawa, S.; Murao, S. PIXE analysis of hair samples from artisanal mining communities in the Acupan region, Benguet, Philippines. Nucl. Instrum. Methods. Phys. Res. B 2004, 219-220, 161-165.

36. WHO/IPCS, Environmental Health Criteria 101, Methylmercury. Available online: http://www.who.int/phe/news/Mercury-flyer.pdf (accessed on 1 December 2014).

37. Voegborlo, R.B.; Akagi, H. Determination of mercury in fish by cold vapour atomic absorption spectrometry using an automatic mercury analyzer. Food Chem. 2007, 100, 853-858.

38. Akagi, H.; Nagamuma, A. Human exposure to mercury and the accumulation of methylmercury that is associated with gold mining in the Amazon Basin, Brazil. J. Health Sci. 2000, 46, 323-328.

39. Cordy, P.; Veiga, M.; Crawford, B.; Garcia, O.; Gonzalez, V.; Moraga, D.; Roeser, M.; Wip, D. Characterization, mapping, and mitigation of mercury vapour emissions from artisanal mining gold shops. Environ. Res. 2013, 125, 82-91.

40. Baeuml, J.; Bose-O'Reilly, S.; Gothe, G.M.; Lettmeier, B.; Roider, G.; Drasch, G.; Siebert, U. Human biomonitoring data from mercury exposed miners in six artisanal small-scale gold mining areas in Asia and Africa. Minerals 2011, 1, 122-143.

41. Gibb, H.; O’Leary, K.G. Mercury exposure and health impacts among individuals in the artisanal and small-scale gold mining community: A comprehensive review. Environ. Health. Perspect. 2014, 122, 667-672.

42. Barbosa, A.C.; Jardim, W.; Dorea, J.G.; Fosberg, B.; Souza, J. Hair mercury speciation as a function of gender, age, amd body mass index in inhabitants of the Negro River Basin, Amazon, Brazil. Arch. Environ. Contam. Toxicol. 2001, 40, 439-444.

43. Pesch, A.; Wilhelm, M.; Rostek, U.; Schmitz, N.; Weishoff-Houben, M.; Ranft, U.; Idel, H. Mercury concentration in urine, scalp hair, and saliva in children from Germany. J. Exposure Analys. Environ. Epidem. 2002, 12, 252-258. 
44. Grandjean, P.; Weihe, P.; White, R.F.; Debes, F.; Araki, S.; Yokoyama, K.; Murata, K.; Sorensen, N.; Dahl, R.; Jorgensen, P.J. Cognitive deficit in 7-year old children in prenatal exposure to methyl mercury. Neurotoxicol. Teratol. 1997,19, 417-428.

45. Harari, R.; Harari, F.; Gerhardson, L.; Lundh, T.; Skerving, S.; Stroemberg, U.; Broberg, K. Exposure and toxic effects of elemental mercury in gold-mining activities in Ecuador. Toxicol. Lett. 2012, 213, 75-82.

46. Tomicic, C.; Vernez, D.; Belem, T.; Berode, M. Human mercury exposure associated with small-scale gold mining in Burkina Faso. Int. Arch. Occup. Environ. Health. 2011, 84, 539-546.

47. Auger, N.; Kofman, O.; Kosatsky, T.; Armstrong, B. Low-level methylmercury exposure as a risk factor for neurologic abnormalities in adults. Neutoxicology 2005,26, 149-157.

48. Zahir, F.; Rivai, S.J.; Haq, S.K.; Khan, R.H. Low dose mercury toxicity and human health. Experiment. Toxicol. Pharmacol. 2005, 205, 351-360.

49. Zillioux, E.J. Mercury in Fish: History, Sources, Pathways, Effects, and Indicator Usage. In Environmental Indicators; Springer Netherland: Dordrecht, The Netherlands, 2015; pp. 743-766.

50. Malm, O.; Branches, F.J.P.; Akagi, H.; Castro, M.B.; Pfeiffer, W.C.; Harada, M.; Bastos, W.R.; Kato, H. Mercury and methylmercury in fish and human hair from the Tapajos river basin, Brazil. Sci. Total Environ. 1995, 175, 141-150.

(C) 2015 by the authors; licensee MDPI, Basel, Switzerland. This article is an open access article distributed under the terms and conditions of the Creative Commons Attribution license (http://creativecommons.org/licenses/by/4.0/). 